\title{
HUBUNGAN PENGETAHUAN DAN PERSONAL HYGIENE DENGAN KEJADIAN TINEA CORPORIS DI DESA KUAPAN WILAYAH KERJA PUSKESMAS XIII KOTO KAMPAR TAHUN 2016
}

\author{
RIANI \\ Dosen FIK Universitas Pahlawan Tuanku Tambusai, Riau, Indonesia
}

\begin{abstract}
ABSTRAK
Tinea Corporis merupakan infeksi jamur superfisial pada daerah kulit halus tanpa rambut, kecuali telapak tangan, telapak kaki.Beberapa faktor yang menyebabkan terjadinya tinea corporis seperti sosial ekonomi rendah, hygiene perorangan yang jelek, lingkungan yang tidak bersih, perilaku yang tidak mendukung, pengetahuan, sikap, kesalahan diagnostik dan perkembangan demografi serta ekologi.Penelitian ini bertujuan untuk mengetahui hubungan pengetahuan dan personal hygiene dengan kejadian tinea corporis di Desa Kuapan Wilayah Kerja Puskesmas XIII Koto KamparTahun 2016. Penelitian ini bersifat analitik dengan menggunakan pendekatan penelitian kasus kontrol (case control study). Sampel dalam penelitian ini untuk kelompok kasus sebanyak 94 kasus dan kelompok kontrol 94dengan teknik pengambilan sampel total sampling untuk kelompok kasus dansistematikrandom sampling untuk kelompok kontrol. Pengolahan data menggunakan analisa univariat dan bivariatkemudian diuji dengan menggunakan uji Chi-square. Hasil penelitian didapatkan bahwa ada hubungan yang bermakna antara pengetahuan dan personal hygiene dengan kejadian tinea corporis di Desa Kuapan Wilayah Kerja Puskesmas XIII Koto Kampar tahun 2016. Untuk itu bagi pihak Puskesmas agar dapat memberikan informasi tentang tinea corporis dan pentingnya menjaga kebersihan diri pada masyarakat.
\end{abstract}

Daftar Bacaan : 19 (2003 - 2015)

Kata Kunci : Pengetahuan, Personal Hygiene, Kejadian Tinea Corporis.

\section{BAB I}

\section{PENDAHULUAN}

\section{A. Latar Belakang}

Penyakit jamur kulit yang merupakan tipe infeksi superficial dan kutan yang dikenal dengan Dermatofitosis.Dermatofitosis mempunyai arti umum, yaitu semua penyakit jamur yang menyerang kulit. Penyakit ini menyerang jaringan yang mengandung zat tanduk yakni epidermis (tinea korporis, tinea kruris, tinea manus etpedis), rambut (tinea kapitis), kuku (tinea unguinum). Terdapat lebih dari 40 spesies dermatofita yang berbeda, yang menginfeksi kulit dan salah satu penyakit yang disebabkan jamur golongan dermatofita adalah tinea korporis (Verma dan Heffernan,2008).

Tinea Korporis, yaitu dermatofitosis yang menyerang daerah kulit yang tidak berambut 
(glabrous skin), misalnya pada wajah, badan, lengan dan tungkai.Gejala subyektifnya yaitu gatal terutama jika berkeringat.Tinea Corporis mengacu pada infeksi jamur superfisial pada daerah kulit halus tanpa rambut, kecuali telapak tangan, telapak kaki.Dinamakan Tinea Corporis karena berdasarkan bagian tubuh yang terkena, yaitu di badan dan anggota badan disebabkan oleh golongan jamur Epidermophyton, Trichophyton, dan Microsporum. Infeksi dimulai dengan kolonisasi hifa dan cabangcabangnya di dalam jaringan keratin yang mati, hifa melepaskan keratinase serta enzim lainnya guna menginvasi lebih dalam stratum korneum dan menimbulkan peradangan, walaupun umumnya, infeksi terbatas pada epidermis, karena adanya mekanisme pertahanan tubuh non spesifik, seperti komplemen, PMN, aktivasi faktor penghambat serum (serum inhibitory factor) namun kadang kadang dapat bertambah atau meluas. Masa inkubasinya sekitar 1-3 minggu (Rianyta, 2009).

Banyak faktor yang menyebabkan terjadinya tinea corporis seperti sosial ekonomi rendah, hygiene perorangan yang jelek, lingkungan yang tidak bersih, perilaku yang tidak mendukung, pengetahuan, sikap, kesalahan diagnostik dan perkembangan demografi serta ekologi (Handoko, 2011). Menurut Rahmanisa (2014) Beberapa faktor pencetus infeksi jamur tinea corporis antara lain kondisi lembab dan panas dari lingkungan, dari pakaian ketat, dan pakaian tak menyerap keringat, keringat berlebihan karena berolahraga atau karena kegemukan, friksi atau trauma minor (gesekan pada paha orang gemuk), keseimbangan flora tubuh normal terganggu (antara lain karena pemakaian antibiotik, atau hormonal dalam jangka

Infeksi dermatofitosis jarang menimbulkan kematian, akan tetapi dapat memberikan efek yang besar terhadap kualitas hidup. Penderita tinea corporis sering merasa terganggu dengan rasa gatal yang disebabkan jamur tersebut .Rasa gatal juga dirasakan bertambah saat penderita berkeringat.

Personal higiene menjadi penting karena personal higiene yang baik akan meminimalkan pintu masuk (port de entry) mikroorganisme yang ada dimana - mana dan pada akhirnya mencegah seseorang terkena penyakit. Personal higiene merupakan langkah awal meminimalkan resiko seseorang terhadap kemungkinan terjangkitnya suatu penyakit, terutama penyakit yang berhubungan dengan kebersihan diri yang buruk. Personal higiene yang tidak baik akan mempermudah tubuh terserang berbagai penyakit, seperti penyakit kulit tinea corporis (Yosella, 2015).

Berdasrkan penelitian yang dilakukan oleh Dosen Akademi Analis Kesehatan Harapan Bangsa Bengkulu (2013) mengatakan bahwa ada hubungan antara personal hygiene dengan penyakit tinea corporis. Personal hygiene merupakan salah satu faktor yang berperan dalam proses pencegahan penyakit kulit tinea corporis.

Dermatofitosis tersebar di seluruh dunia dan menjadi masalah terutama di negara berkembang.Berdasarkan urutan kejadian dermatofitosis, tinea korporis $(57 \%)$, tinea unguinum $(20 \%)$, tinea kruris $(10 \%)$, tinea pedis dan tinea barbae (6\%), dan sebanyak $1 \%$ tipe lainnya.Di 
berbagai negara saat ini terjadi peningkatan bermakna dermatofitosis. Di Kroasia dilaporkan prevalensi dermatofitosis 26\% pada tahun 1986 dan meningkat menjadi $73 \%$ pada tahun 2001. Di Amerika Serikat penderita tinea korporis mencapai $10-20 \%$ dari kunjungan ke RS Arizona Regional Medical Center Hospital bagian divisi Poli Jamur Kulit dan angka ini akan meningkat pada daerah yang lebih panas. Di Malaysia didapatkan prevalensi tinea korporis sebesar 30,63\% dari 180 pasien yang datang ke Klinik Kulit RS Queen Elizabeth pada tahun 2007-2009. Di Filipina insidensi tinea korporis menduduki urutan kedua sebanyak 22,63\% setelah Pityriasis versicolor $25,34 \%$ sepanjang tahun 2000-2003. Di Kimitsu Chuo Hospital, Tokyo Jepang, kasus tinea korporis adalah sebesar 11,9\%. Insidensi ini menduduki urutan ketiga setelah tinea pedis $(64,2 \%)$, diikuti tinea unguium (14,6\%) (Mustafa et al,2013).

Tinea Corporis merupakan infeksi yang umum terjadi pada daerah dengan iklim hangat, lembab, sekitar 47\% disebabkan oleh Trichophyton Rubrum.Di indonesia, dermatofitosis merupakan $52 \%$ dari seluruh dermatomikosis dan tinea kruris dan tinea korporis merupakan dermatofitosis terbanyak. Insidensi tinea korporis di berbagai rumah sakit pendidikan dokter di Indonesia yang menunjukkan angka persentase bervariasi dari $2,93 \%$ yang terendah di Semarang sampai $27,6 \%$ yang

Tabel 1.2 : Data Kunjungan Kejadian Tinea Corporis Berdasarkan Umur di Desa Desa KuapanWilayah Kerja Puskesmas XIII Koto Kampar dari Bulan Januari - September Tahun 2016

\begin{tabular}{lrcc}
\hline No & Umur & Jumlah & Persentase \\
\hline 1. & $14-25$ Tahun & 67 & 33,0 \\
2. & $26-40$ Tahun & 94 & 46,3 \\
\hline
\end{tabular}

tertinggi di Padang. Laki - laki pasca pubertas lebih banyak terkena tinea corporis dibanding wanita, Tinea korporis dapat terjadi pada semua usia, paling sering mengenai usia 18 - 25 tahun serta 40 - 50 tahun.

Berdasarkan data penderita tinea corporis di Desa KuapanWilayah Kerja Puskesmas XIII Koto Kampar dari tahun 2013 sampai 2015 dapat dilihat pada tabel berikut ini :

$\begin{array}{lccc}\text { Tabel 1.1 : } & \begin{array}{l}\text { Penderita } \\ \text { Corporis }\end{array} & \begin{array}{r}\text { Tinea } \\ \text { di Desa }\end{array} \\ \text { KuapanWilayah } \\ \text { Kerja Puskesmas XIII } \\ \text { Koto } \\ \end{array}$

Berdasarkan tabel diatas dapat dilihat bahwa penderita tinea corporis di Desa KuapanWilayah Kerja Puskesmas XIII Koto Kampar dari tahun 2013 sampai 2015 terjadi penurunan kasus penyakit tinea corporis yaitu sebesar 7,2 \% . Sedangkan pada tahun 2015 terjadi peningkatan kasus penderita tinea corporis yaitu mencapai $8,2 \%$. Berdasarkan data penderita tinea corporis berdasrkan umur di Desa Kuapan Wilayah Kerja Puskesmas XIII Koto Kampar dari bulan Januari - September tahun 2016 dapat dilihat pada tabel berikut ini : 


\begin{tabular}{lrr}
\hline $3 . \quad 45-65$ Tahun \\
\hline \multicolumn{4}{c}{ Total } \\
\hline Berdasarkan tabel diatas dapat \\
dilihat bahwa penderita & tinea \\
corporis & di Desa Desa
\end{tabular}

KuapanWilayah Kerja Puskesmas XIII Koto Kampar dari Bulan Januari - September Tahun 2016 paling banyak diderita kelompok umur 26 - 40 tahun yaitu sebesar $46,3 \%$. Secara langsung usia tidak berpengaruh terhadap terjadinya tinea corporis tetapi faktor risiko terkena tinea corporis terjadi pada usia 26 - 40 tahun karena pada masa ini merupakan masih aktif dalam kegiatan sehari - hari atau memiliki kesibukan yang tinggi sehingga sering mengabaikan personal hygienenya sendiri dan berakibat mudah terkena penyakit kulit seperti tinea corporis terutama masyarakat menengah kebawah (Rekam Medik, 2016).

Berdasarkan survey awal yang peneliti lakukan pada 10 orang di Desa Kuapan Puskesmas XIII Koto Kampar tentang penyakit tinea corporis, 7 orang menyatakan tidak mengetahui tentang tinea corporis dan 3 orang menyatakan mengetahui tinea corporis hanya sebatas penyakit yang biasa masyarakat sebut dengan borok. Dari pantauan peneliti mengenai kondisi personal hygiene terlihat $80 \%$ masyarakat tidak menjaga kebersihan diri mereka. Berdasarkan fenomena diatas maka peneliti tertarik untuk melakukan penelitian tentang faktor - faktor yang berhubungan dengan kejadian tinea corporis di Desa Kuapan Puskesmas XIII Koto Kampar.

\section{B. Rumusan Masalah}

Rumusan masalah penelitian ini adalah "apakah ada hubungan faktor
$42 \quad 20,7$

203100

pengetahuan dan personal hygiene dengan kejadian tinea corporis di Desa Kuapan Puskesmas XIII Koto Kampar tahun 2016".

C. Tujuan Penulisan

1. Tujuan Umum

Untuk mengetahuihubungan faktor pengetahuan dan personal hygiene terhadap kejadian tinea corporis Tahun 2016.

\section{Tujuan Khusus}

a. Untuk mengetahui gambaran kejadian tinea corporis di Desa Kuapan Puskesmas XIII Koto Kampar Tahun 2016.

b. Untuk mengetahui gambaran pengetahuan tentang tinea corporis di Desa Kuapan Puskesmas XIII Koto Kampar Tahun 2016.

c. Untuk mengetahui gambaran personal hygiene di Desa Kuapan Puskesmas XIII Koto Kampar Tahun 2016.

d. Untuk menganalisa hubungan pengetahuan tentang tinea corporis dengan kejadian tinea corporis di Desa KuapanPuskesmas XIII Koto KamparTahun 2016.

e. Untuk menganalisa hubungan personal higiene dengan kejadian tinea corporis di Desa KuapanPuskesmas XIII Koto Kampar Tahun 2016.

\section{Manfaat Penelitian}

\section{Aspek Teoritis}

a. Sebagai informasi dan referensi bacaan bagi tenaga kesehatan terutama perawat mengenai penyebab yang berhubungan dengan kejadian tinea corporis.

b. Sebagai bahan masukan dan kajian yang dapat dijadikan sumbangan pemikiran dan informasi untuk penelitian 
masa mendatang dan dapat dijadikan sebagai bahan kepustakaan.

\section{Aspek praktis}

a. Diharapkan penelitian ini dapat dijadikan sumber pengetahuan dan bahan informasi untuk penelitian sejenis atau penelitian lanjutan tentang tinea corporis, serta dapat menambah wawasan dan pengalaman dalam mengaplikasikan ilmu - ilmu yang diproleh selama kuliah ditengah masyarakat.

b. Hasil penelitian ini diharapkan dapat menjadi sumber informasi bagi petugas kesehatan di Puskesmas Jambu Kabupaten Rokan Hilir, dalam upaya menurunkan jumlah kejadian tinea corporis.

\section{BAB III}

\section{METODE PENELITIAN}

\section{A. Desain Penelitian}

Penelitian ini bersifat analitik dengan menggunakan pendekatan penelitian kasus kontrol (case control study) adalah penelitian epidemiologi analitik observasional yang mengkaji

1. Rancangan Penelitian hubungan antara efek (dapat berupa penyakit atau kondisi kesehatan) tertentu dengan faktor risiko tertentu yaitu penelusuran apakah ada hubungan antara pengetahuan dan sikap dengan kejadian tinea corporis pada pasien penderita tinea corporis di Puskesmas Bagansiapiapi. Studi dimulai dengan mengidentifikasi kelompok kasus dengan kelompok kontrol, kemudian secara retrospektif (penelusuran ke belakang) diteliti dengan faktor risiko yang sudah menerangkan apakah kasus dan kontrol terkena paparan atau tidak (Supardi, 2013). Dalam penelitian ini, kelompok kasus (pasien yang terdiagnosis mengalami tinea corporis yang diketahui melalui rekam medik) dibandingkan dengan kelompok kontrol (pasien yang berobat di Puskesmas XIII Koto Kampar pada tahun 2015 yang tidak terdiagnosis tinea corporis yang diketahui melalui rekam medik). Penelitian ini bertujuan untuk mengetahui hubungan antara pengetahuan, personal hygiene dan sikap dengan kejadian tinea corporis di Desa KuapanPuskesmas XIII Koto Kampar Tahun 2016.






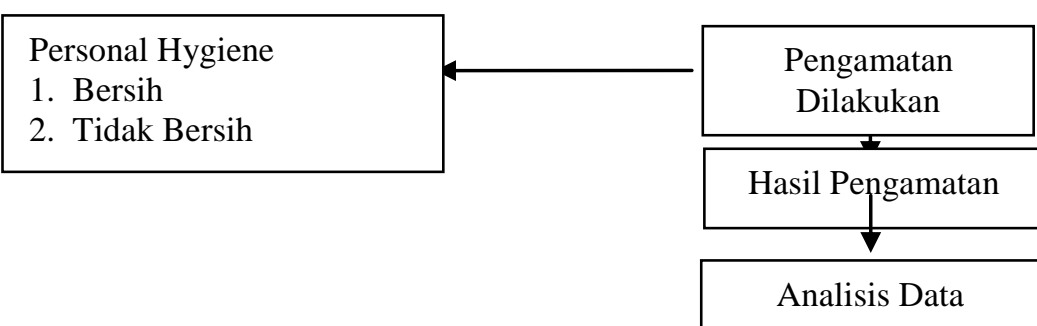

Sumber: Supardi (2013)

Skema 3.1 : Rancangan Penelitian

2. Alur Penelitian

Secara skematis alur penelitian ini dapat di lihat pada skema 3.2 di bawah ini :

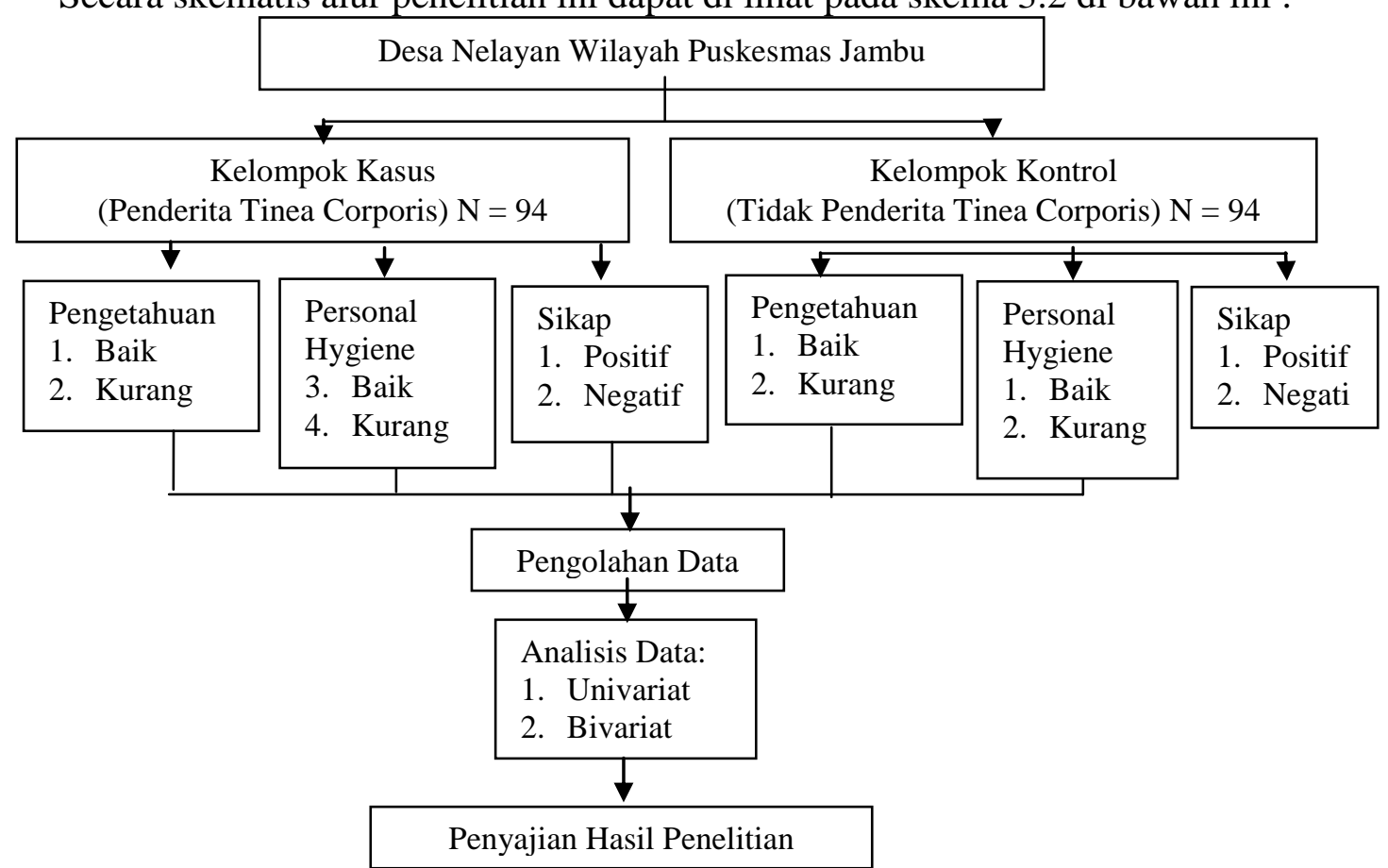

Skema 3.2 : Alur Penelitian

\section{B. Lokasi dan Waktu Penelitian}

Penelitian ini dilakukan pada tanggal 04 - 30 Januari tahun 2016 di Desa KuapanPuskesmas XIII Koto Kampar

\section{Populasi dan Sampel}

\section{Populasi}

Populasi

merupakan keseluruhan atau totalitas objek yang diteliti yang ciri - cirinya akan diduga atau ditaksir (estimated) (Nasir, 2011). Populasi penelitian ini adalah seluruh masyarakat yang datang berobat ke Puskesmas Jambu Tahun 2015 yang berjumlah 562 orang.

\section{Sampel}

Sampel adalah sebagian yang diambil dari keseluruhan objek yang diteliti yang dianggap mewakili seluruh populasi (Notoadmajo, 2005). Adapun sampel dalam penelitian untuk kelompok kontrol diambil semua kasus tinea corporis usia 26 
tahun - 60 tahun di Puskesmas XIII Koto Kampar tahun 2015 sebanyak 94 kasus. Sedangkan kelompok kontrol yaitu semua masyarakat yang berobat ke Puskesmas XIII Koto Kampar yang diambil dari jumlah populasi $=562$ $-94=468$ orang. Maka jumlah kelompok kontrol penderita tinea corporis juga menggunakan perbandingan 1: 1 yaitu sebanyak 94 sampel kontrol. Sampel yang akan diambil berasal dari populasi penelitian yang memenuhi kriteria inklusi.

a. Kriteria Sampel

1) Kriteria Inklusi

Kriteria inklusi adalah kriteria dimana subjek penelitian dapat mewakili dalam sampel penelitian yang memenuhi syarat sebagai berikut :

a) Kelompok Kasus

(1) Penderita tinea corporis (usia 26 - 60 tahun) yang pernah datang berobat di Puskesmas Jambu yang memiliki catatan data identitas lengkap yang peneliti perlukan (umur, pendidikan dan pekerjaan).

b) Kelompok Kontrol

Seluruh data rekam medik pasien non tinea corporis.

2) Kriteria eksklusi

Kriteria eksklusi adalah kriteria dimana subjek penelitian tidak dapat mewakili syarat sebagai sampel penelitian yaitu :

\section{Analisa Data}

\section{Anlisa Univariat}

Analisa univariat yaitu dilakukan untuk menganalisa terhadap distribusi frekuensi setiap kategori pada variabel bebas (pengetahuan, personal hygiene dan sikap) dan variabel terikat (tinea corporis).Hal ini dilakukan untuk memproleh a) Kelompok Kasus

(1)Data rekam medik yang tidak lengkap sesuai variabel yang diteliti (umur, pendidikan, dan pekerjaan).

(2)Penderita tinea corporis yang pindah rumah pada saaat penelitian dilakukan

b) Kelompok Kontrol

Seluruh data rekam medik pasien dewasa yang berobat di Puskesmas Jambu.

b. Teknik Pengambilan Sampel

1) Pengambilan sampel pada kelompok kasus yaitu dengan teknik total Sampling yaitu pengambilan sampel secara keseluruhan yang berjumlah 94 orang.

2) Pengambilan sampel pada kelompok kontrol diambil dengan teknik sistematik random sampling, yaitu pengambilan sampel yang dilakukan secara acak dan sistematis dengan cara jumlah populasi dibagi dengan jumlah sampel (468: $94=5$ ), jadi sampel yang diambil dalam penelitian ini adalah responden dengan nomor urut kelipatan 5 untuk sampel pertama kontrol. Apabila pada random pertama diambil nomor sampel 15 maka kelipatan selanjutnya adalah 15 , 20, 25, dan seterusnya sampai jumlah sampel 94 orang.

gambaran masing - masing variabel independen dan dependen, selanjutnya dilakukan analisa terhadap tampilan data tersebut. Analisa data dilakukan setelah data terkumpul, data tersebut di klasifikasikan menurut variabel yang diteliti, dan data dioleh secara manual dengan 
menggunakan rumus distribusi frekuensi sebagai berikut :

$\mathrm{F}$
$\mathrm{P}=\mathrm{X}$
$\mathrm{N}$

\section{Keterangan :}

$\mathrm{P}$ : Persentase

F : Frekuensi jawaban yang benar

N : Jumlah Sampel (Budiarto, 2002).

\section{Analisa Bivariat}

Analisa bivariat digunakan untuk mengetahui faktor - faktor yang berhubungan dengan kejadian tinea corporis. Data dianalisis dengan dibantu program SPSS (Statistical Product and Service Solutions). Dalam analisis data dibedakan tingkatannya, yaitu : analisis univariat dan bivariat. Analisis bivariat menggunakan tabel silang untuk menganalisis hubungan antara dua variabel. Menguji ada tidaknya hubungan antara variabel pengetahuan, sikap, dan personal hygiene dengan kejadian tinea corporis digunakan analisis $C h i$ Square, dengan tingkat kemaknaan $\alpha=0,05$. Hasil yang diperoleh pada analisis Chi Square dengan menggunakan program komputer yaitunilai $p$, kemudian dibandingkan dengan $\alpha$ $=0,05$. Apabila nilai probabilitas $(\mathrm{P}) \leq \alpha(0,05) \mathrm{H}_{0}$ ditolak artinya ada hubungan antara dua variabel dan apabila probabilitas $(\mathrm{P})>\alpha$
$(0,05) \mathrm{H}_{0}$ diterima artinya tidak ada hubungan antara dua variable (Dahlan, 2009).

Analisis data dalam penelitian case control dengan menghitung odds ratio (OR). Menurut Cotton, kekuatan hubungan dua variabel secara kualitatif dapat dibagi dalam 4 area yaitu :

1. $\mathrm{r}=0,00-0,25 \rightarrow$ tidak ada hubungan/hubungan lemah

2. $\mathrm{r}=0,26-0,50 \longrightarrow$ hubungan sedang

3. $r=0,51-0,75 \rightarrow$ hubungan kuat

4. $r=0,76-1,00 \rightarrow$ hubungan sangat kuat atau sempurna (Hastono, 2007)

\section{BAB IV \\ HASIL PENELITIAN}

Penelitian ini dilakukan pada tanggal 04 - 30 Januari 2017 yang meliputi responden di Desa Nelayan Wilayah Kerja Puskesmas Jambu Kabupaten Rokan Hilir Tahun 2016, yang berjumlah 188 orang, 94 orang respoden yang menderita tinea corporis dan 94 orang responden yang tidak menderita tinea corporis. Data yang diambil pada penelitian ini meliputi karakteristik responden (umur, jenis kelamin,pendidikan dan pekerjaan), pengetahuan,sikap dan personal hygiene (variabel Independen) dan kejadian tinea corporis (variabel dependen) yang diukur dengan kuesioner. Selanjutnya hasil penelitian disajikan dalam bentuk tabel sebagai berikut :

\section{A. Karakteristik Responden}

\section{Umur}

Tabel 4.1 Distribusi Frekuensi Responden Berdasarkan Umur di Desa Kuapan Wilayah Kerja XIII Koto Kampar Tahun 2016

\begin{tabular}{cccccc}
\hline \multirow{2}{*}{ No } & \multirow{2}{*}{ Umur } & \multicolumn{2}{c}{ Kelompok Kasus } & \multicolumn{2}{c}{ Kelompok Kontrol } \\
\cline { 3 - 6 } & & $\mathbf{N}$ & Persentase $(\boldsymbol{\%})$ & $\mathbf{N}$ & Persentase (\%) \\
\hline 2. & $\mathbf{2 6}-\mathbf{3 5}$ Tahun & $\mathbf{4 8}$ & $\mathbf{5 1 , 1}$ & $\mathbf{5 1}$ & $\mathbf{5 4 , 3}$ \\
\hline 3. & $36-45$ Tahun & 19 & 20,2 & 21 & 22,3 \\
\hline
\end{tabular}




\begin{tabular}{clcccc}
\hline 4. & $>46$ Tahun & 27 & 28,7 & 22 & 23,4 \\
\hline & Jumlah & 94 & 100 & 94 & 100 \\
\hline
\end{tabular}

Keterangan : Hasil Penelitian

Berdasarkan tabel 4.1 di atas dapat dilihat bahwa responden kelompok kasus dan kelompok kontrol pada rentang usia 26 - 35

tahun sebanyak 48 orang $(51,1 \%)$ pada kelompok kasus dan 51 orang $(54,3 \%)$ pada kelompok kontrol.

2. Jenis Kelamin

Tabel4.2 Distribusi Frekuensi Responden Berdasarkan Jenis Kelamin diDesa Kuapan Wilayah Kerja XIII Koto Kampar Tahun 2016

\begin{tabular}{clcccc}
\hline \multirow{2}{*}{ No } & Pendidikan & \multicolumn{2}{c}{ Kelompok Kasus } & \multicolumn{2}{c}{ Kelompok Kontrol } \\
\cline { 3 - 6 } & & $\mathbf{N}$ & Persentase (\%) & $\mathbf{N}$ & Persentase (\%) \\
\hline 1. & Laki - laki & 46 & 48,9 & 40 & 42,5 \\
\hline 2. & Perempuan & $\mathbf{4 8}$ & $\mathbf{5 1 , 1}$ & $\mathbf{5 4}$ & $\mathbf{5 7 , 5}$ \\
\hline & Jumlah & 94 & 100 & 94 & 100 \\
\hline
\end{tabular}

Keterangan : Hasil Penelitian

Berdasarkan tabel 4.2 di atas dapat dilihat bahwa pada kelompok kasus maupun kelompok kontrol paling banyak responden berjenis kelamin

perempuan yaitu sebanyak 48 responden $(51,1 \%)$ sedangkan pada kelompok kontrol sebanyak 54 responden $(57,5 \%)$.

\section{Pendidikan}

Tabel4.3 Distribusi Frekuensi Responden Berdasarkan Pendidikan di Desa Kuapan Wilayah Kerja XIII Koto Kampar Tahun 2016

\begin{tabular}{clcccc}
\hline \multirow{2}{*}{ No } & Pendidikan & \multicolumn{2}{c}{ Kelompok Kasus } & \multicolumn{2}{c}{ Kelompok Kontrol } \\
\cline { 3 - 6 } & & $\mathbf{N}$ & Persentase (\%) & $\mathbf{N}$ & Persentase (\%) \\
\hline 1. & SD & $\mathbf{4 9}$ & $\mathbf{5 2 , 1}$ & 18 & 19,1 \\
\hline 2. & SMP & 20 & 21,3 & 20 & 21,3 \\
\hline 4. & Perguruan Tinggi & 25 & 26,6 & $\mathbf{5 6}$ & $\mathbf{5 9 , 5}$ \\
\hline & Jumlah & 94 & 100 & 94 & 100 \\
\hline
\end{tabular}

Keterangan : Hasil Penelitian

Berdasarkan tabel 4.3 di atas dapat dilihat bahwa responden kelompok kasus sebagian besar berpendidikan SD sebanyak 49 orang $(52,1 \%)$, sedangkan pada kelompok kontrol responden sebagian besar berpendidikan perguruan tinggi sebanyak 56 orang $(59,5 \%)$.

\section{Pekerjaan}

Tabel4.4 Distribusi Frekuensi Responden Berdasarkan Pekerjaan di Desa Kuapan Wilayah Kerja XIII Koto Kampar Tahun 2016

\begin{tabular}{clcccc}
\hline \multirow{2}{*}{ No } & Pendidikan & \multicolumn{2}{c}{ Kelompok Kasus } & \multicolumn{2}{c}{ Kelompok Kontrol } \\
\cline { 3 - 6 } & & $\mathbf{N}$ & Persentase (\%) & $\mathbf{N}$ & Persentase (\%) \\
\hline 1. & IRT & $\mathbf{2 8}$ & $\mathbf{2 9 , 8}$ & 18 & 19,1 \\
\hline 2. & Wiraswasta & 17 & 18,1 & 20 & 21,3 \\
\hline 3. & Tidak Bekerja & 8 & 8,5 & 10 & 10,6 \\
\hline 4. & Buruh & 18 & 19,1 & 21 & 22,4 \\
\hline $\mathbf{5 .}$ & Nelayan & 23 & 24,5 & $\mathbf{2 5}$ & $\mathbf{2 6 , 6}$ \\
\hline & Jumlah & 94 & 100 & 94 & 100 \\
\hline
\end{tabular}

Keterangan : Hasil Penelitian

Berdasarkan tabel 4.4 di atas dapat dilihat bahwa pada kelompok kasus paling banyak responden bekerja sebagai IRT yaitu sebanyak 28 orang $(29,8 \%)$, sedangkan pada kelompok kontrol paling banyak responden bekerja 
sebagai nelayan sebanyak 25 orang $(26,6 \%)$.

\section{B. Analisa Univariat}

1. Pengetahuan

Tabel 4.5 Distribusi Frekuensi Pengetahuan Responden Tentang Tinea Corporis di Desa Kuapan Wilayah Kerja XIII Koto Kampar Tahun 2016

\begin{tabular}{cccccc}
\hline \multirow{2}{*}{ No } & Pengetahuan & \multicolumn{2}{c}{ Kelompok Kasus } & \multicolumn{2}{c}{ Kelompok Kontrol } \\
\cline { 3 - 6 } & & $\mathbf{N}$ & Persentase (\%) & $\mathbf{N}$ & Persentase (\%) \\
\hline 1. & Baik & 38 & 40,4 & $\mathbf{7 1}$ & $\mathbf{7 5 , 5}$ \\
\hline 2. & Kurang & $\mathbf{5 6}$ & $\mathbf{5 9 , 6}$ & 23 & 24,5 \\
\hline & Jumlah & 94 & 100 & 94 & 100 \\
\hline
\end{tabular}

Keterangan : Hasil Penelitian

Berdasarkan tabel 4.5 di atas dapat dilihat bahwa pada kelompok kasus sebagian besar responden dikategorikan memilili pengetahuan kurang tentang Tinea

kelompok kontrol mayoritas responden memiliki pengetahuan baik tentang Tinea Corporis yaitu sebanyak 71 rorang $(75,5 \%)$.

Corporis yaitu sebanyak 38 orang $(59,6 \%)$ sedangkan pada

\section{Personal Hygiene}

Tabel 4.7 Distribusi Frekuensi Personal Hygiene Responden di Desa Kuapan Wilayah Kerja XIII Koto Kampar Tahun 2016

\begin{tabular}{cccccc}
\hline \multirow{2}{*}{ No } & Personal Hygiene & \multicolumn{2}{c}{ Kelompok Kasus } & \multicolumn{2}{c}{ Kelompok Kontrol } \\
\cline { 3 - 6 } & & $\mathbf{N}$ & Persentase (\%) & $\mathbf{N}$ & Persentase (\%) \\
\hline 1. & Bersih & 36 & 38,3 & $\mathbf{5 9}$ & $\mathbf{6 2 , 8}$ \\
\hline 2. & Tidak Bersih & $\mathbf{5 8}$ & $\mathbf{6 1 , 7}$ & 35 & 37,2 \\
\hline & Jumlah & 94 & 100 & 94 & 100 \\
\hline
\end{tabular}

Keterangan : Hasil Penelitian

Berdasarkan tabel 4.7 di atas dapat dilihat bahwa pada kelompok kasus sebagian besar responden memiliki personal hygiene tidak bersih sebanyak 58

orang $(61,7 \%)$ sedangkan pada kelompok kontrol sebagian besar responden memiliki personal hygiene bersih sebanyak 59 orang $(62,8 \%)$.

\section{Kejadian Tinea Corporis}

Tabel 4.8 Distribusi Frekuensi Berdasarkan Kejadian Tinea Corporis di Desa Kuapan Wilayah Kerja XIII Koto Kampar Tahun 2016

\begin{tabular}{ccccccc}
\hline \multirow{2}{*}{$\begin{array}{c}\text { Kejadian Tinea } \\
\text { Corporis }\end{array}$} & \multicolumn{3}{c}{ Kelompok Sampel } & \multicolumn{2}{c}{ Jumlah } \\
\cline { 2 - 5 } & \multicolumn{2}{c}{ Kasus } & \multicolumn{2}{c}{ Kontrol } & & \\
\cline { 2 - 5 } & $\mathbf{N}$ & $\boldsymbol{\%}$ & $\mathbf{N}$ & $\mathbf{\%}$ & $\mathbf{N}$ & $\boldsymbol{\%}$ \\
\hline Ya & 94 & 100 & 0 & 0 & 94 & 50,0 \\
\hline Tidak & 0 & 0 & 94 & 100 & 94 & 50,0 \\
\hline Jumlah & 94 & $100 \%$ & 94 & $100 \%$ & 188 & 100,0 \\
\hline
\end{tabular}

Keterangan : Hasil Penelitian

Berdasarkan tabel 4.8 diatas dapat dilihat bahwa kejadian pada kelompok kasus sebanyak 94 orang $(50,0 \%)$ sedangkan pada kelompok kontrol sebanyak 94 orang $(50,0 \%)$.

\section{Analisa Bivariat}

Analisa bivariat digunakan untuk mengetahui hubungan pengetahuan, dan personal hygiene terhadap kejadian tinea corporis di Desa Kuapan Wilayah Kerja XIII Koto Kampar Tahun 2016, dengan menggunakan uji statistik Chi- 
Square $\left(\mathrm{X}^{2}\right)$, dengan derajat kepercayaan $\alpha<0,05$.

\section{Hubungan Pengetahun Tentang Tinea Corporis dengan Kejadian Tinea Corporis}

Tabel 4.9 Hubungan Pengetahuan Responden Tentang Tinea Corporis dengan Kejadian Tinea Corporis di Desa Kuapan Wilayah Kerja XIII Koto Kampar Tahun 2016

\begin{tabular}{|c|c|c|c|c|c|c|c|c|}
\hline \multirow[t]{3}{*}{ Pengetahuan } & \multicolumn{4}{|c|}{ Kejadian Tinea Corporis } & \multicolumn{2}{|c|}{ Jumlah } & \multirow{2}{*}{\multicolumn{2}{|c|}{ P Value OR }} \\
\hline & \multicolumn{2}{|c|}{ Kasus } & \multicolumn{2}{|c|}{ Kontrol } & & & & \\
\hline & $\mathbf{N}$ & $\%$ & $\mathbf{N}$ & $\%$ & $\mathbf{N}$ & $\%$ & 0,000 & 4,549 \\
\hline Kurang & 56 & 59,6 & 23 & 24,5 & 79 & 42,0 & & \\
\hline Baik & 38 & 40,4 & 71 & 75,5 & 109 & 58,0 & & \\
\hline Total & 94 & 100 & 94 & 100 & 188 & 100 & & \\
\hline
\end{tabular}

Keterangan : Hasil Penelitian

Berdasarkan tabel 4.9 di atas dapat dilihat dari 94 responden tinea corporis (kasus) terdapat 38 responden $(40,4 \%)$ berpengetahuan baik. Sedangkan dari 94 responden yang tidak mengalami tinea corporis (kontrol) terdapat 23 responden $(41,0 \%)$ berpengetahuan kurang. Berdasarkan uji statistik dengan person Chi-Square, maka diperoleh nilai $\mathrm{P}$ value $0,000(\mathrm{P}$

Berdasarkan tabel 4.10 di atas dapat dilihat dari 94 responden tinea corporis (kasus) terdapat 35 responden $(37,2 \%)$ bersikap positif. Sedangkan dari 94 responden yang tidak mengalami tinea corporis (kontrol) terdapat 37 responden $(39,4 \%)$ bersikap negatif. Berdasarkan uji statistik dengan person Chi-Square, maka diperoleh nilai $\mathrm{P}$ value $0,002(\mathrm{P}<$ $0,05)$ pada drajat kemaknaan $\alpha$ $(0,05)$ dengan menggunakan tingkat kepercayaan $95 \%$ yang berarti ada hubungan siakp dengan kejadian tinea corporis. Berdasarkan hasil OR (Odd Ratio) diatas 0,385 yang berarti

\begin{tabular}{|c|c|c|c|c|c|c|c|c|}
\hline \multirow{3}{*}{$\begin{array}{l}\text { Personal } \\
\text { Hygiene }\end{array}$} & \multicolumn{4}{|c|}{ Kejadian Tinea Corporis } & \multirow{2}{*}{\multicolumn{2}{|c|}{ Jumlah }} & \multirow{2}{*}{\multicolumn{2}{|c|}{ P Value OR }} \\
\hline & \multicolumn{2}{|c|}{ Kasus } & \multicolumn{2}{|c|}{ Kontrol } & & & & \\
\hline & $\mathbf{N}$ & $\%$ & $\mathbf{N}$ & $\%$ & $\mathbf{N}$ & $\%$ & 0,001 & 2,716 \\
\hline Tidak Bersih & 59 & 62,8 & 36 & 38,3 & 95 & 50,5 & & \\
\hline Bersih & 35 & 37,2 & 58 & 61,7 & 93 & 49,5 & & \\
\hline Total & 94 & 100 & 94 & 100 & 188 & 100 & & \\
\hline
\end{tabular}

$<0,05)$ pada derajat kemaknaan $\alpha$ $(0,05)$ dengan menggunakan tingkat kepercayaan $95 \%$ yang berarti ada hubungan pengetahuan dengan kejadian tinea corporis. Berdasarkan hasil OR (Odd Ratio) diatas 4,549 maka responden yang berpengetahuan kurang tentang tinea corporis akan berpeluang 4,549 kali berisiko mengalami tinea corporis di bandingkan yang berpengetahuan baik.

hubungan kedua variabel termasuk dalam kategori sedang, maka responden yang bersikap negatif terhadap tinea corporis akan berpeluang 0,385 kali berisiko mengalami tinea corporis di bandingkan yang bersikap positif.

2. Hubungan Personal Hygiene dengan Kejadian Tinea Corporis

Tabel 4.11Hubungan Personal Hygiene dengan Kejadian Tinea Corporis di Desa Kuapan Wilayah Kerja XIII Koto Kampar $\begin{array}{lr}\text { Tahun } & 2016\end{array}$ 
Keterangan : Hasil Penelitian

Berdasarkan tabel 4.11 di atas dapat dilihat dari 94 responden tinea corporis (kasus) terdapat 35 responden $(37,2 \%)$ memiliki personal hygiene bersih. Sedangkan dari 94 responden yang tidak mengalami tinea corporis (kontrol) terdapat 36 responden $\quad(38,3 \%)$ memiliki personal hygiene tidak bersih. Berdasarkan uji statistik dengan person Chi-Square, maka diperoleh nilai $\mathrm{P}$ value $0,001(\mathrm{P}<$ $0,05)$ pada drajat kemaknaan $\alpha$ $(0,05)$ dengan menggunakan tingkat kepercayaan $95 \%$ yang berarti ada hubungan personal hygiene dengan kejadian tinea corporis. Berdasarkan hasil OR (Odd Ratio) diatas 2,716 maka responden yang memiliki personal hygiene tidak bersih akan berpeluang 2,716 kali berisiko mengalami tinea corporis di bandingkan yang memiliki personal hygiene bersih.

\section{BAB V}

\section{PEMBAHASAN}

\section{A. Pembahasan Penelitian}

Hasil penelitian yang telah dilakukan terhadap 94orang responden yang terdiagnosa tinea corporis dan 94 orang responden yang tidak terdiagnosa tinea corporis tentang "hubungan pengetahuan dan personal hygiene dengan kejadianTinea Corporis di Desa Kuapan Wilayah Kerja XIII Koto Kampar Tahun 2016" sebagai berikut :

\section{Hubungan Pengetahuan}

Tentang Tinea Corporis di Desa Kuapan Wilayah Kerja XIII Koto Kampar Tahun 2016

Berdasarkan penelitian dari tabel 4.9 diketahui bahwa hasil uji statistik hubungan pengetahuan responden tentang tinea corporis di Desa Kuapan Wilayah Kerja XIII Koto Kampar Tahun 2016 diproleh hasil P Value $(0,000)$ sehingga Ho ditolak pada derajat kemaknaan 0,05 berarti ada hubungan pengetahuan tentang tinea corporis dengan kejadian tinea corporis. Dimana responden pada kelompok kasus (terdiagnosa tinea corporis)banyak berpengetahuan kurang, sedangkan pada kelompok kontrol (tidak terdiagnosa tinea corporis) banyak responden berpengetahuan baik.

Berdasarkan penelitian diatas maka peneliti berasumsi bahwa pengetahuan seseorang berpengaruh dalam prilaku seseorang dalam bertindak khusunya dalam bidang kesehatan. Responden yang memiliki pengetahuan baik tentang tinea corporis maka resiko terkena tinea corporis semakin kecil, hal ini dikarenakan karenc responden yang memilik pengetahuan baik tentang tinea corporis akan memproteksi dirinya untuk terhindar dari penyakit tinea corporis dan menghindari faktor - faktor pencetus tinea corporis. Pada responden yang memiliki pengetahuan kurang tentang tinea corporis maka risiko dirinya terkena tinea corporis lebih besar. Pengetahuan yang kurang tentang tinea corporis akan membuat responden menjadi kurang protektif atau mengabaikan faktor - faktor yang dapat menyebabkan dirinya terjangkit penyakit tinea corporis seperti kurang memperhatikan personal hygiene anak dan kebersihan lingkungan tempat tinggal. 
Berdasarkan penelitian diatas responden yang memiliki pengetahuan baik juga terdapat anaknya terkena tinea corporis sebesar 21 orang $(40,4 \%)$. Hal ini membuktikan bahwa tidak hanya faktor pengetahuan yang berperan dalam kejadian tinea corporis tetapi adanya faktor lain yang menyebabkan terjadinya tinea corporis. Pada responden yang memiliki pengetahuan kurang tentang tinea corporis memang lebih berisiko terkena tinea corporis, tetapi pengetahuan responden tentang tinea corporis tidak menjadi penentu secara mutlak seseorang terkena tinea corporis atau tidak, karena tinea corporis disebabkan oleh jamur yang berhubungan erat dengan kondisi lingkungan tempat tinggal dan kelembaban suhu.

Salah satu faktor yang menyebabkan terjadinya tinea corporis adalah kurangnya pengetahuan tentang tinea corporis. Berdasarkan penelitian yang dilakukan Heiyana (2010) tentang hubungan tingkat pengetahuan tinea pedis (Athlete's Foot) dan perilaku pencegahan terhadap kejadian tinea pedis (Athlete's Foot) pada pemain sepak bola, menunjukkan hasil bahwa terdapat korelasi kuat antara tingkat pengetahuanterhadap kejadian tinea corpolis $(\mathrm{p}=0,000$; $\mathrm{r}=0,649$ ). Berdasarkan penelitian yang dilakukan oleh Pratiwi (2013) diproleh hasil bahwa terdapat hubungan positif dan signifikan antara pengetahuan tentang tinea corporis dengan kejadian tinea corpporis.

Berdasarkan hasil penelitian tersebut dapat dilihat bahwa semakin baik pengetahuan responden tentang tinea corporis, maka semakin kecil kemungkinan menderita tinea corporis. Hal ini sesuai dengan teori yang dikemukakan oleh Notoatmodjo (2007) yang mengatakan pengetahuan atau kognitif merupakan domain yang sangat penting untuk terbentuknya tindakan seseorang. Dari pengalaman dan penelitian ternyata perilaku yang didasari oleh pengetahuan akan lebih langgeng daripada perilaku yang tidak didasari oleh pengetahuan. Menurut Engel, Blackwell dan Miniard (1995) dikutip oleh Ali Khomsan (2009) yang mengatakan pengetahuan adalah informasi yang disimpan dalam ingatan dan menjadi penentu utama perilaku seseorang. Pengetahuan seseorang dapat dapat dipengaruhi oleh kemampuan intelektualnya. Pengetahuan akan berpengaruh terhadap sikap dan perilaku seseorang karena berhubungan dengan daya nalar, pengalaman, dan kejelasan konsep mengenai objek tertentu.

Pengetahun yang baik pada kelompok responden tidak terdiagnosa tinea corporis didukung oleh pendidikan responden yang paling banyak berpendidikan tamatan perguruan tinggi sebesar $37,2 \%$. Hal ini sesuai dengan pendapat yang dikemukakan oleh Notoadmojo (2007) bahwa pendidikan mempengaruhi proses belajar, makin tinggi pendidikan seeorang makin mudah orang tersebut untuk menerima informasi. Dengan pendidikan tinggi maka seseorang akan cenderung untuk mendapatkan informasi, baik dari 
orang lain maupun dari media massa. Semakin banyak informasi yang masuk semakin banyak pula pengetahuan yang didapat tentang kesehatan. Pengetahuan sangat erat kaitannya dengan pendidikan dimana diharapkan seseorang dengan pendidikan tinggi, maka orang tersebut akan semakin luas pula pengetahuannya.

\section{Hubungan Personal Hygiene} dengan kejadian Tinea Corporis di Desa Kuapan Wilayah Kerja XIII Koto Kampar Tahun 2016

Berdasarkan penelitian dari tabel 4.11 diketahui bahwa hasil uji statistik Hubungan personal hygiene dengan kejadian tinea corporis di Desa Kuapan Wilayah Kerja XIII Koto Kampar Tahun 2016 diproleh hasil $P$ Value $(0,001)$ sehingga Ho ditolak pada derajat kemaknaan 0,05 berarti ada hubungan personal hygiene dengan kejadian tinea corporis. Dimana responden pada kelompok kasus (terdiagnosa tinea corporis)banyak memiliki personal hygiene tidak bersih, sedangkan pada kelompok kontrol (tidak terdiagnosa tinea corporis) banyak responden memiliki personal hygiene bersih.

Berdasarkan penelitian diatas maka peneliti berasumsi bahwa sikap seseorang berpengaruh dalam prilaku seseorang dalam bertindak khusunya dalam bidang kesehatan.Responden yang memiliki sikap positif terhadap tinea corporis akan dapat mencegah dirinya terjangkit tinea corporis. Responden yang kurang memiliki kesadaran yang baik dalam memandang penyakit tinea corporis akan berdampak menderita tinea corporis yang dapat menganggu aktivatasnya sehari - hari akibat gatalnya dirasakan penderita tinea corporis. Responden yang memiliki sikap positif juga terdapat menderita tinea corporis sebesar 19 orang $(36,5 \%)$. Hal ini membuktikan bahwa masih ada faktor lain yang berperan dalam kejadian tinea corporis selain sikap responden.

Responden yang memiliki personal hygiene bersih sangat penting dalam menentukan seseorang menderita tinea corporis atau tidak. Seseorang yang memperhatikan kebersihan dirinya dan lingkunganya akan meminimalkan dirinya terkena penyakit tinea corporis. Walaupun dalam penelitian ini responden yang memiliki personal hygiene masih menderita corporis, dapat disebabkan banyak faktor salah satunya berat badan berlebih atau obesitas.Begitu juga sebaliknya responden yang memiliki personal hygiene tidak bersih idak menderita tinea corporis dapat disebabkan oleh jenis kulitnya yang tidak sensitif.

Penelitian ini sesuai dengan penelitian yang dilakukan oleh Dosen Akademi Analis Kesehatan Harapan Bangsa Bengkulu (2011), tentang Hubungan Personal Hygiene Dengan Penyakit Kulit Di Sdn 38 Kuala Alam Kecamatan Ratu Agung Kota Bengkulu.Hasil penelitian menunjukkan ada hubungan antara personal hygiene dengan penyakit kulit di SDN 38 Kuala Alam Kecamatan Ratu Agung Kota Bengkulu.

Penelitian ini sesuai dengan teori yang dikemukakan oleh Yosella (2015) personal higiene menjadi penting karena personal 
higiene yang baik akan meminimalkan pintu masuk (port de entry) mikroorganisme yang ada dimana-mana dan pada akhirnya mencegah seseorang terkena penyakit. Kebersihan diri merupakan langkah awal mewujudkan kesehatan diri.Dengan tubuh yang bersih meminimalkan resiko seseorang terhadap kemungkinan terjangkitnya suatu penyakit, terutama penyakit yang berhubungan dengan kebersihan diri yang buruk seperti tinea corporis. Personal higiene yang tidak baik akan mempermudah tubuh terserang berbagai penyakit, seperti penyakit kulit seperti tinea corporis dan dapat menghilangkan fungsi bagian tubuh tertentu sepertinya halnya kulit.

Kulit merupakan lapisan terluar dari tubuh dan bertugas melindungi jaringan tubuh di bawahnya dan organ-organ yang lainnya terhadap luka, dan masuknya berbagai macam mikroorganisme ke dalam tubuh.Untuk itu diperlukan perawatan terhadap kesehatan dan kebersihan kulit. Menjaga kebersihan kulit dan perawatan kulit ini bertujuan meminimalkan setiap ancaman dan gangguan yang akan masuk melewati kulit. Sebagai organ proteksi peranan kulit tidak luput dari berbagai masalah-masalah yang bisa membahayakan kulit itu sendiri. Untuk selalu memelihara kebersihan kulit kebiasaankebiasaan yang sehat harus selalu diperhatikan seperti, menggunakan barang-barang keperluan sehari-hari milik sendiri, mandi minimal 2x sehari, mandi memakai sabun, menjaga kebersihan pakaian, makan yang bergizi terutama banyak sayur dan buah, dan menjaga kebersihan lingkungan.

\section{DAFTAR PUSTAKA}

Boel T. (2003). Mikosis Superfisial. Fakultas Kedoteran Gigi. Universitas Sumatera Utara. Diakses Pada Tanggal 15 Oktober 2016 dari http://Repository.Usu.Ac.Id/Bitstr eam/123456789/1174/1/FkgTrelia1.Pdf.

Dosen Akademi Analis Kesehatan Harapan Bangsa Bengkulu. (2013).Hubungan Personal Hygiene Dengan Penyakit Kulit Di Sdn 38 Kuala Alam Kecamatan Ratu Agung Kota Bengkulu. Diakses Pada Tanggal 04 Oktober 2016 Dari Http://Www.Google.Co.Id/Urlrapl es.Pdf.

Epimulyani.(2011).Hubungan Tingkat Pendidikan Dan Pengetahuan Dengan Kejadian Penyakit Dermatomikosis Di Poli Kulit Dan Kelamin RSUD Kajen Kabupaten Pekalongan. Skripsi Fakultas Ilmu Keperawatan Dan Kesehatan. Universitas Muhammadiyah, Semarang.

Fransisca.(2006). Tinea.Fakultas. Kedokteran Universitas Wijaya Kusuma Surabaya. Diakse Pada Tanggal 10 Oktober 2016 Dari https://Last3arthtree.Files.Wordpr ess. Com/2009/ 02/Tinea.Pdf.

Handoko. (2011). Faktor - Faktor Yang Berhubungan Dengan Kejadian Tinea Corporis.

Hidayat, A.A. (2009). Metode Penelitian Keperawatan Dan Teknik Analisa Data. Jakarta, Salemba Medika. 
Iskandar A.(2010). Metodologi Penelitian Pendidikan dan Sosial (Kuantitatif danKualitatif).Jakarta : GP Press.

Korompis,G.(2015).Biostatistik Untuk Keperawatan. Jakarta : EGC.

Nasir, Dkk. (2011). Metodologi Penelitian Kesehatan. Yogyakarta : Mulia Medika.

Notoatmodjo, S. (2010). Ilmu Prilaku Kesehatan. Jakarta : Rineka Cipta. (2007). Promosi Kesehatan Dan Ilmu Perilaku. Jakarta, Rineka Cipta.

Nursalam.(2008). Konsep Dan Penerapan Metodologi Penelitian Keperawatan, Jakarta.

Profil Puskesmas Jambu Kabupaten Rokan Hilir Tahun 2013 - 2015. : Penderita Tinea Corporis Di Desa Nelayan Wilayah Kerja Puskesmas Jambu Dari Tahun 2013 Sampai 2015.

Riantya. (2009). Dermatofitosis E.C Tinea Corporis.Laporan Kasus Propinsi Kepulauan Bangka Belitung, Indonesia. Diakses Pada Tanggal 04 Oktober 20162016 Dari

Http://Www.Kalbemed.Com/Port als/6/12_183dermatofitosis.Pdf.

Saraswati.(2010). Tinea Korporis. Jurnal Fakultas Kedokteran Universitas Udayana/Rumah Sakit Umum Pusat Sanglah Denpasar.

Seam, Z.(2012). Psikologi Keperawatan. Jakarta : Rajawali Pers.

Supardi.(2013). Aplikasi Statistika Dalam Penelitian Konsep Statistika Yang LebihKomprehensif. Jakarta, Change Publication.

Verma,S.,Heffernan,M.P.(2008).Superfi sial Fungal Infection:Dermatophytosis, Tinea Nigra, Piedra. Dalam: Wolff, K. (Eds). Fitzpatrick's Dermatology
In General Medicine. Vol.II. Ed.7. United States: Mcgraw- Hill.

Yossela T. (2015). Diagnosis And Treatment Of Tinea Cruris. Artikel Review Faculty Of Medicine, University Of Lampung. 